\title{
ALTERNATIF STRATEGI PENGEMBANGAN PELABUHAN KUALA TANJUNG - SUMATERA UTARA
}

\author{
Alternative Strategies for the Development of Kuala Tanjung Port, North Sumatera
}

Oleh:

\author{
Amril Syahputra Rangkuti ${ }^{1 *}$, Budhi Hascaryo Iskandar ${ }^{2}$, Kirbandoko ${ }^{3}$, Deni \\ Achmad Soeboer ${ }^{2}$ \\ ${ }^{1}$ Pusat Kajian Sumberdaya Pesisir dan Lautan, Institut Pertanian Bogor \\ ${ }^{2}$ Departemen Pemanfaatan Sumberdaya Perikanan, Fakultas Perikanan dan Ilmu \\ Kelautan, Institut Pertanian Bogor \\ ${ }^{3}$ Sekolah Bisnis, Institut Pertanian Bogor \\ *Korespondensi: amril@pksplipb.or.id
}

\begin{abstract}
ABSTRAK
Pelabuhan adalah tempat yang terdiri dari daratan dan perairan di sekitarnya dengan batas-batas tertentu sebagai tempat kegiatan pemerintah dan kegiatan ekonomi yang dipergunakan sebagai tempat kapal bersandar, berlabuh, naik turun penumpang dan bongkar muat barang yang dilengkapi dengan fasilitas keselamatan pelayaran dan kegiatan penunjang pelabuhan serta sebagai tempat perpindahan intra dan moda transportasi. Pelabuhan Kuala Tanjung memiliki posisi yang sangat strategis karena terletak pada jalur pelayaran dunia. Dengan berada pada jalur pelayaran internasional (terletak di Selat Malaka), maka terbuka peluang untuk menjadi salah satu pelabuhan andalan.

Faktor internal dan eksternal Pelabuhan Kuala Tanjung berpengaruh besar terhadap pengembangan pelabuhan dan daerah di sekitarnya. Dengan kekuatan, kelemahan, peluang, dan ancaman yang terdapat pada Pelabuhan Kuala Tanjung. Manajeman harus memanfaatkan Pelabuhan Kuala Tanjung dengan skala proritas untuk jangka pendek mendorong pemerintah pusat dan daerah untuk mengoptimalkan Pelabuhan Kuala Tanjung yang memiliki nilai strategis. Strategi jangka menengah Pelabuhan Kuala Tanjung dapat dijadikan international hub port untuk mendukung pertumbuhan perekonomian nasional. Strategi jangka panjang memperkuat posisi Pelabuhan Kuala Tanjung Sebagai international hub port di Selat Malaka.
\end{abstract}

Kata kunci: Pelabuhan Kuala Tanjung dan alternatif strategi.

\begin{abstract}
Seaport is a region which consists of land surrounded by seawater with a certain limit as a place of government and economics activities that are used as a ship to berth, dock, boarding/unboarding passengers, and loading/unloading cargoes which equipped with maritime safety and other port support facilities as well as a place for rearranging different intra and multimodal transportation. Kuala Tanjung Port holds a very strategic position since it's located at one of the busiest shipping lane in the world. Being in an important international shipping lane (located in the Malacca Strait); there should be an opportunity to become one of the backbone port.
\end{abstract}

Internal and external factors of Kuala Tanjung Port have a major influence for the port development and its surrounding area. Based on its strength, weakness, opportunities and threats, the port management must utilize with a priority scale on their development strategy. Short terms strategy is encouraging the central and regional governments to optimize the Port of Kuala Tanjung which has 
strategic value. The medium-term strategy of Kuala Tanjung Port is becoming an international hub port to support national economic growth. And the Long-term strategy is strengthening the position of the Kuala Tanjung Port as an international hub port in the Malacca Strait.

Keywords: Kuala Tanjung Port and Strategic Alternatives.

\section{PENDAHULUAN}

Pelabuhan merupakan pintu utama untuk aliran barang baik ekspor maupun impor mempunyai peran penting dan stategis Pelabuhan Kuala Tanjung terbuka untuk perdagangan luar negeri serta sekaligus merupakanpelabuhan antar pulau yang menghubungkan pulau-pulau dengan pelabuhan sekitarnya,namun tidak terdapat pelayanan dan aktivitas naik turun penumpang.

Menurut Bichou (2013), perencanaan pelabuhan adalah proses di mana beberapa topik yang terkait dengan investasi pelabuhan, kapasitas desain, operasi, strategi, dan kebijakan ditangani secara bersamaan. Hal ini juga terkait dengan aktivitas pelabuhan baik yang terletak di daerah perairan laut dan/atau di pedalaman. Hal lain yang juga diperhatikan dalam perencanaan pelabuhan adalah sistem transportasi, sistem logistik yang lebih luas dan sistem rantai pasok. Tujuan inti dari perencanaan pelabuhan adalah untuk mencari keseimbangan antara kekurangan kapasitas dan over-kapasitas pada tingkat biaya, harga dan layanan yang memadai. Semua hal itu sangat menentukan pengambilan keputusan yang berkaitan dengan produktivitas operasional dan optimalisasi, berbagai kebijakan terkait dan faktor sosial (Port Planing and Developing, 2013).

Beberapa kajian menunjukan bahwa 20 tahun mendatang aliran peti kemas di Indonesia akan meningkat secara dramatis dari 8,8 juta TEUs pada tahun 2009 diperkirakan akan menjadi 30 juta TEUs pada tahun 2020 dan 48 juta TEUs pada 2030, namun pada sisi lain wilayah hinterland Pelabuhan Kuala Tanjung didominasi perkebunan sawit yang meliputi Asahan, Simalungun, Labuhan Batu, dan wilayah sekitarnya dimana pada tahun 2009 mencapai 1.291 .080 ton dengan pertumbuhan 5\% per tahun (Kemenhub RI, 2016). Dengan pengembangan Sei Mangke sebagai kawasan industri diharapkan akan memberikan dampak yang signifikan bagi perkembangan Pelabuhan Kuala Tanjung. Pengembangan Sei Mangke diharapkan dapat meningkatkan potensi throughput Pelabuhan Kuala Tanjung.

Pelabuhan Kuala Tanjung berbatasan secara langsung dengan Selat Malaka, dan memiliki akses yang mudah dengan Singapura dan Malaysia. Ini menjadi salah satu potensi yang terdapat di Pelabuhan Kuala Tanjung, sehingga disebut layak di dalam Rencana Induk Pelabuhan (RIP) untuk dikembangkan menjadi pelabuhan ekspor impor internasional. Berdasarkan kebijakan pemerintah yang tertuang dalam Peraturan Menteri Perhubungan No 20 Tahun 2012 tentang Rencana Induk Palabuhan Kuala Tanjung maka Pelabuhan Kuala Tanjung merupakan jenis pelabuhan hub port yang diharapkan dapat bersaing dengan pelabuhan hub port lainnya seperti Tanjung Pelepas Malaysia dan Port of Singapore. Sebagai pelabuhan hub port internasional maka Pelabuhan Kuala Tanjung akan dikembangkan menjadi pelabuhan kontainer yang diharapkan dapat bersaing dengan pelabuhan kontainer yang sudah ada seperti Pelabuhan Penang, Pelabuhan Port Klang, Pelabuhan Tanjung Pelepas, Pelabuhan Singapore yang saat ini mendominasi pasar kontainer di dunia.

Kondisi eksisting Pelabuhan Kuala Tanjung saat ini merupakan pelabuhan yang memiliki potensi hinterland yang terdiri dari banyak perkebunan kelapa sawit. Pengembangan Pelabuhan Kuala Tanjung diarahkan kepada pengembangan terminal curah cair dan curah kering serta fasilitas pendukungnya. Industri kelapa sawit (dalam bentuk CPO, kernel maupun PKO) merupakan industri strategis, terutama di wilayah Provinsi Sumatera Utara dan sekitarnya termasuk Provinsi Nanggroe Aceh Darussalam (NAD) dan Provinsi Riau. Perkembangan industri kelapa sawit ini juga menuntut perkembangan sarana, akomodasi dan transportasi produk, dari pusat produksi menuju pusat distribusi yang dapat dijadikan peluang uantuk mengembangkan Pelabuhan Kuala Tanjung pada tahap awal. 
Berdasarkan uraian di atas, diperlukan perencanaan sejak dini melalui telaah strategi yang baik untuk pegembangan Pelabuhan Kuala Tanjung. Tujuan dari penelitian ini adalah untuk mendapatkan kondisi ekstisting Pelabuhan Kuala Tanjung dan mendapatkan strategis pengembangan Pelabuhan Kuala Tanjung.

\section{METODE PENELITIAN}

Penelitian ini dilakukan pada bulan Januari - Mei 2018 dengan menggunakan metode survei. Survei dilakukan di Pelabuhan Kuala Tanjung Sumatra Utara. Pengolahan serta analisis data dilakukan di Sekolah Bisnis IPB.

Data yang dibutuhkan bersumber dari Rencana Induk Pelabuhan Indonesia yang telah disusun oleh Direktorat Jenderal Perhubungan Laut Kementerian Perhubungan Republik Indonesia. Data selanjutnya dikelompokkan sesuai sifatnya sebelum dianalisis. Analisis data menggunakan analisis SWOT (Strength, Weakneses, Opportinity dan Threat). Metode SWOT yang digunakan menggunakan pendekatan Evaluasi Faktor Eksternal (EFE) dan Evaluasi Faktor Internal (IFE).

Matriks IFE menyediakan informasi penting bagi perumusan strategi. Alat perumusan strategi ini meringkas dan mengevaluasi kekuatan dan kelemahan utama dalam area-area utama bisnis dan juga menjadi landasan dalam mengevaluasi dan mengidentifikasi hubungan antara area tersebut. Area yang dapat dikembangkan merupakan area yang telah diidentifikasi faktor-faktor penting dalam melakukan analisis tersebut.

External factor evaluation (EFE) menurut David (2012) adalah salah satu alat untuk mengevaluasi kondisi ekonomi, sosial budaya, demografi lingkungan, politik, pemerintahan, aspek legal, perkembangan teknologi dan aspek kompetitif lainnya. Analisis eksternal ini bertujuan untuk mengidentifikasi faktor-faktor ekstenal kunci yang menjadi peluang dan ancaman dalam merumuskan stategi pengembangan.

Matriks SWOT merupakan alat yang dipakai untuk menyusun faktor-faktor strategis perusahaan yang dapat menggambarkan peluang dan ancaman eksternal yang dihadapi perusahaan sehingga dapat dilakukan penyesuaian terhadap kekuatan dan kelemahan yang dimiliki oleh perusahaan tersebut. Matriks SWOT merupakan matching tool yang penting untuk membantu para manajer mengembangkan empat tipe strategi, yaitu :

a. Strategi SO (Strength-Opportunity)

Strategi ini menggunakan kekuatan internal perusahaan dalam meraih peluang yang ada di luar perusahaan. Jika perusahaan memiliki banyak kelemahan, maka perusahaan harus mengatasi kelemahan itu agar menjadi kuat. Sedangkan, jika perusahaan menghadapi banyak ancaman, perusahaan harus berusaha menghindarinya dan berkonsentrasi pada peluang yang ada.

b. Strategi WO (Weakness-Opportunity).

Strategi ini bertujuan memperkecil kelemahan internal perusahaan dengan memanfaatkan peluang eksternal. Perusahaan menghadapi kesulitan untuk memanfaatkan peluang karena adanya kelemahan internal. Alternatif untuk mengatasi masalah kesenjangan teknologi ini adalah mengadakan suatu kerja sama dengan perusahaan lain yang lebih kompeten.

c. Strategi ST (Strength-Threat).

Strategi ini bertujuan untuk menghindari dampak ancaman eksternal.

d. Strategi WT (Weakness-Threat).

Strategi ini bertujuan untuk bertahan dengan cara mengurangi kelemahan internal serta menghindari ancaman. Perusahaan yang dihadapkan pada sejumlah kelemahan internal dan ancaman eksternal berada dalam posisi yang berbahaya. 
David (2010), menjelaskan delapan langkah dalam membuat matriks SWOT, yaitu:

Tabel 1 Matriks SWOT

\begin{tabular}{|c|c|c|}
\hline Analisis Eksternal & $\begin{array}{l}\text { Kekuatan (Strength-S) } \\
1 \ldots . . \\
2 \ldots . . \\
3 \text { Dsb }\end{array}$ & $\begin{array}{l}\text { Kelemahan (Weakness-W) } \\
1 \ldots \\
2 \ldots . . \\
3 \text { Dsb }\end{array}$ \\
\hline $\begin{array}{l}\text { Peluang (Oppotunity- O) } \\
1 \ldots . . \\
2 \ldots . . \\
3 \mathrm{Dsb}\end{array}$ & $\begin{array}{l}\text { Strategi S-O } \\
\text { Memanfaatkan kekuatan } \\
\text { untuk menarik } \\
\text { keuntungan dari peluang }\end{array}$ & \begin{tabular}{l}
\multicolumn{1}{c}{ Strategi W-O } \\
Memperbaiki kelemahan \\
dengan mengambil \\
keuntungan dari peluang
\end{tabular} \\
\hline $\begin{array}{l}\text { Ancaman (Threats-T) } \\
1 \ldots . \\
2 \ldots . \\
3 \text { Dsb }\end{array}$ & $\begin{array}{l}\quad \text { Strategi S-T } \\
\text { Menggunakan kekuatan } \\
\text { untuk menghindari } \\
\text { ancaman }\end{array}$ & $\begin{array}{l}\text { Strategi W-T } \\
\text { Mengurangi kelemahan serta } \\
\text { menghindari ancaman }\end{array}$ \\
\hline
\end{tabular}

Sumber : David (2010)

\section{HASIL DAN PEMBAHASAN}

\section{Kondisi Umum Pelabuhan}

Pelabuhan Kuala Tanjung terletak di Pantai Timur Provinsi Sumatera Utara dan secara administratif berada di Kabupaten Batu Bara dengan letak geografis pada posisi 030 22' 30" LU dan 990 26’ 00" BT. Beroperasi sejak tahun 1981 dan dibangun sebagai pelabuhan penunjang untuk kegiatan Pabrik PT. INALUM.

Pelabuhan Kuala Tanjung terbuka untuk perdagangan luar negeri serta sekaligus merupakan pelabuhan antar pulau yang menghubungkan pulau-pulau dengan pelabuhan sekitarnya, namun tidak terdapat pelayanan dan aktivitas naik turun penumpang. Dari posisi geografis, letaknya sangat strategis karena berhadapan langsung dengan Selat Malaka dan berpotensi sebagai pelabuhan penunjang bagi Pelabuhan Belawan terutama untuk komoditi curah dikarenakan tingkat kepadatan trafik yang sangat tinggi di Pelabuhan Belawan, kepadatan di Pelabuhan Belawan didominasi oleh cargo container dapat dilihat dari callyang terjadi pada tahun 2013, 2014, dan 2015 seperti diperlihatkan pada Tabel 2 berikut ini.

Tabel 2 Jumlah Call kapal kontainer berdasarkan negara bendera

\begin{tabular}{lrrr}
\hline \multicolumn{1}{c}{ Negara/Tahun } & $\mathbf{2 0 1 3}$ & $\mathbf{2 0 1 4}$ & $\mathbf{2 0 1 5}$ \\
\hline Marshall Island & 18.399 & 27.451 & 27.707 \\
Panama & 25.542 & 21.677 & 19.823 \\
Malaysia & 26.974 & 26.542 & 27.038 \\
Liberia & 5.208 & 5.208 & 15.470 \\
Indonesia & 10.029 & 10.277 & 10.097 \\
Singapura & 36.421 & 35.663 & 37.333 \\
Cyprus & 35.485 & 33.345 & 33.272 \\
Antiagua & 5.840 & 5.840 & 5.840 \\
Hongkong & 56.097 & 59.873 & 60.342 \\
\hline
\end{tabular}

Sumber: Laporan tahunan Pelabuhan Belawan 2013, 2014, 2015 dalam Nainggolan et al,2017

Pelabuhan Kuala Tanjung sebagai pelabuhan penunjang bagi rencana Kawasan Industri Sei Mangke yang diarahkan sebagai Kawasan Ekonomi Khusus. Gambar 1 menunjukkan posisi Pelabuhan Kuala Tanjung. 


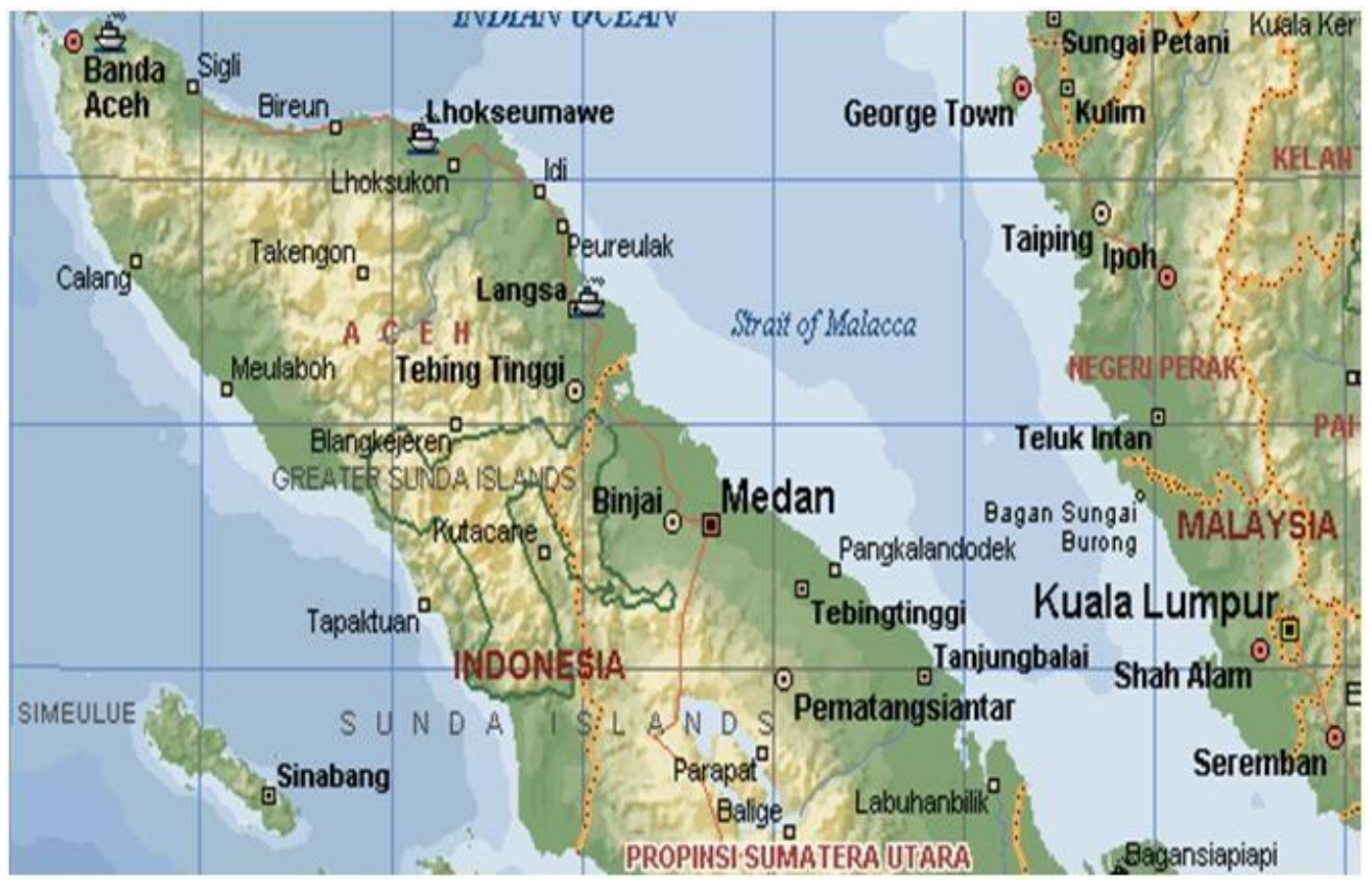

Sumber : Rencana Induk Pelabuhan Kuala Tanjung (2012)

Gambar 2 Peta lokasi Pelabuhan Kuala Tanjung

\section{Identifikasi Faktor Internal dan Eksternal}

Evaluasi pada faktor internal dan eksternal dilakukan untuk mengetahui faktor-faktor dari dalam pelabuhan baik yang menjadi kekuatan atau kelemahan dari Pelabuhan Kuala Tanjung. Terdapat total 10 faktor internal yang terdiri dari 5 sebagai kekuatan (strength) dan 5 sebagai kelemahan (weaknesess) :

\section{A. Kekuatan}

1. Letak geografis strategis di jalur perdagangan dunia (Selat Malaka)

2. Wilayah interland pelabuhan dalam kawasan KEK Sei Mangke pertumbuhan industri 5\%/tahun.

3. Pelabuhan Kuala Tanjung masuk dalam program nasional master plan percepatan, perluasan dan pembangunan ekonomi Indonesia (MP3EI) Wilayah Barat.

4. Pelabuhan Kuala Tanjung masuk ke dalam Rencana Induk Pelabuhan Nasional (RIPN).

5. Perairan pelabuhan memiliki kedalaman 20 LWS.

B. Kelemahan

1. Lamanya pembangunan infrastruktur (2012-2018).

2. Alokasi dana yang belum tercukupi mencapai $\pm \mathrm{Rp} 37,8 \mathrm{~T}$.

3. Tingkat koordinasi instansi pemerintah (pusat dan daerah) masih terbatas.

4. Akses jalan yang belum menggunakan jalan nasional.

5. Penggunan teknologi operasional pelabuhan yang belum optimal.

Evaluasi terhadap faktor eksternal terdiri dari Peluang (Oppotunity- O) dan Ancaman. Peluang adalah kondisi di luar pelabuhan yang apa bila dapat direspon dengan baik oleh pelabuhan maka akan dapat meningkatkan pengembangan Pelabuhan Kuala Tanjung ke depannya. Ancaman adalah kondisi di luar perusahaan yang bersifat negatif dan apabila tidak diantisipasi oleh pelabuhan maka akan dapat melemahkan pelabuhan tersebut.

C. Peluang

1. Adanya kawasan industri Sei Mangke di sekitar lokasi pelabuhan. 
2. Jalur perdagangan dunia dengan jumlah petikemas yang lewat 51 jt TEU's.

3. Pelabuhan Kuala Tanjung dapat menjadi international hub port di wilayah barat Indonesia dengan pengembangan mencapai 25 jt TEU's.

4. Pelabuhan Kuala Tanjung menjadi pendukung pelabuhan sebelumnya (Belawan dan Dumai)

5. Dapat menurunkan biaya logistik kawasan.

D. Ancaman

1. Pelabuhan pesaing di Selat Malaka (Singapura dan Malaysia) yang menyerap pasar $80 \%$.

2. Cina berkeinginan membuka jalur baru pelayaran dunia.

3. Pertumbuhan industri di Indonesia hanya 5\% per tahun.

4. Penurunan produksi daerah interland karena konversi lahan perkebunan.

5. Ketidakpastian hukum dan investasi.

Setelah dilakukan identifikasi terhadap faktor internal dan eksternal, data lalu dikelompokkan dan dianalisis menjadi faktor-faktor SWOT ke dalam matriks SWOT. Matriks SWOT adalah langkah yang harus dilakukan untuk merumuskan strategi yang akan dilakukan dalam pengembangan pelabuhan tersebut. Matriks analisis SWOT tersebut terdapat pada Tabel 2.

Setelah melakukan analisis SWOT maka faktor-faktor internal dan eksternal tersebut dapat dilakukan pembobotan atau penilaian. Penilaian ini dilakukan untuk melihat faktor yang paling penting. Faktor paling penting ini dapat dijadikan strategi proritas dalam pengembangan pelabuhan tersebut. Pada Tabel 3 di bawah ini terdapat pembobotan atau penilaian dari faktor-faktor yang terdapat pada analisis SWOT.

Tabel 2 Matriks Analisis SWOT

\begin{tabular}{|c|c|c|}
\hline Analisis Internal & $\begin{array}{l}\text { Kekuatan (Strength-S) } \\
\text { 1. Letak geografis strategis di jalur } \\
\text { perdagangan dunia (Selat Malaka) } \\
\text { 2. Wilayah interland pelabuhan } \\
\text { dalam kawasan KEK Sei Mangke } \\
\text { pertumbuhan industri 5\%/tahun } \\
\text { 3. Pelabuhan Kuala Tanjung masuk } \\
\text { dalam program nasional master } \\
\text { plan percepatan, perluasan dan } \\
\text { pembangunan ekonomi Indonesia } \\
\text { (MP3EI) Wilayah Barat } \\
\text { 4. Pelabuhan Kuala Tanjung masuk } \\
\text { ke dalam Rencana Induk } \\
\text { Pelabuhan Nasional (RIPN) } \\
\text { 5erairan pelabuhan memiliki } \\
\text { kedalaman } 20 \text { LWS }\end{array}$ & $\begin{array}{l}\text { Kelemahan ( Weakness-W) } \\
\text { 1. Lamanya pembangunan } \\
\text { infrastruktur (2012-2018) } \\
\text { 2. Alokasi dana yang belum } \\
\text { tercukupi mencapai } \pm \mathrm{Rp} \\
\text { 37,8 T } \\
\text { 3. Tingkat koordinasi } \\
\text { instansi pemerintah } \\
\text { (pusat dan daerah) masih } \\
\text { terbatas } \\
\text { 4. Akses jalan yang belum } \\
\text { menggunakan jalan } \\
\text { nasional } \\
\text { 5. Penggunaan teknologi } \\
\text { operasional pelabuhan } \\
\text { yang belum optimal. }\end{array}$ \\
\hline
\end{tabular}




\begin{tabular}{|c|c|c|}
\hline $\begin{array}{l}\text { Peluang (Oppotunity- O) } \\
\text { 1. Adanya kawasan } \\
\text { industri Sei Mangke } \\
\text { di sekitar lokasi } \\
\text { pelabuhan } \\
\text { 2. Jalur perdagangan } \\
\text { dunia dengan jumlah } \\
\text { petikemas yang lewat } \\
51 \text { jt TEU's } \\
\text { 3. Pelabuhan Kuala } \\
\text { Tanjung dapat } \\
\text { menjadi international } \\
\text { hub port di wilayah } \\
\text { barat Indonesia } \\
\text { dengan } \\
\text { pengembangan } \\
\text { mencapai } 25 \text { jt TEU's } \\
\text { 4. Pelabuhan Kuala } \\
\text { Tanjung menjadi } \\
\text { pendukung pelabuhan } \\
\text { sebelumnya (Belawan } \\
\text { dan Dumai) } \\
\text { 5. Dapat menurunkan } \\
\text { biaya logistik kawasan } \\
\text { (estimasi 10\%) }\end{array}$ & \begin{tabular}{l}
\multicolumn{1}{c}{ Strategi S-O } \\
Mengoptimalkan letak Pelabuhan \\
Kuala Tanjung yang stategis dan \\
kedalaman perairan untuk \\
mengambil pasar perairan dunia dan \\
menjadi internasional hub port. (s1, \\
s3, s4-o1, o2, o3, o5)
\end{tabular} & $\begin{array}{l}\quad \text { Strategi W-O } \\
\text { Mendorong pemerintah } \\
\text { untuk menyediakan } \\
\text { kebutuhan infrastruktur } \\
\text { dalam rangka memanfaatkan } \\
\text { potensi Pelabuhan Kuala } \\
\text { Tanjung dan penurunan } \\
\text { biaya logistik } \\
\text { (w1, w2, w3, w5-o1, o3, o4, } \\
\text { o5) }\end{array}$ \\
\hline $\begin{array}{ll}\text { Ancaman (Threats-T) } \\
\text { 1. Pelabuhan pesaing di } \\
\text { Selat Malaka } \\
\text { (Singapura dan } \\
\text { Malaysia) yang } \\
\text { menyerap pasar } 80 \% \\
\text { 2. Cina berkeinginan } \\
\text { membuka jalur baru } \\
\text { pelayaran dunia } \\
\text { 3. Pertumbuhan } \\
\text { industri di Indonesia } \\
\text { hanya 5\%/tahun } \\
\text { 4. Penurunan produksi } \\
\text { daerah interland } \\
\text { karena konversi lahan } \\
\text { perkebunan } \\
\text { 5. Ketidakpastian } \\
\text { hukum dan investasi }\end{array}$ & \begin{tabular}{l}
\multicolumn{1}{c}{ Strategi S-T } \\
Menguatkan posisi strategis \\
Pelabuhan Kuala Tanjung dan tidak \\
ikut mendukung pembukaan jalur \\
baru pelayaran dunia (s1, s5, -t1, t2, \\
t3)
\end{tabular} & $\begin{array}{l}\quad \text { Strategi W-T } \\
\text { Mangambil pasar yang ada di } \\
\text { Selat Malaka dengan } \\
\text { melakukan pelayanan } \\
\text { pelabuhan yang lebih baik } \\
\text { dari pelabuhan lainnya di } \\
\text { Selat Malaka (w1, w2, w3, - } \\
\mathrm{t} 1, \mathrm{t} 2, \mathrm{t} 5)\end{array}$ \\
\hline
\end{tabular}


Tabel 3 Pembobotan Nilai Faktor-faktor Analisis SWOT

\begin{tabular}{|c|c|c|c|c|}
\hline SWOT & ANALISIS LINGKUNGAN & Bobot & Rat & Skor \\
\hline & INTERNAL & & & \\
\hline \multirow{6}{*}{$\begin{array}{l}\text { Kekuatan } \\
\quad(S)\end{array}$} & $\begin{array}{l}\text { Letak geografis strategis di jalur perdagangan dunia (Selat } \\
\text { Malaka) }\end{array}$ & 0,8860 & 4 & 3,54 \\
\hline & $\begin{array}{l}\text { Wilayah interland pelabuhan dalam kawasan KEK Sei } \\
\text { Mangke dengan pertumbuhan industru 5\%/tahun }\end{array}$ & 0,0886 & 3 & 0,27 \\
\hline & $\begin{array}{l}\text { Pelabuhan Kuala Tanjung masuk dalam program nasional } \\
\text { master plan percepatan, perluasan dan pembangunan } \\
\text { ekonomi Indonesia (MP3EI) Wilayah Barat }\end{array}$ & 0,0246 & 2 & 0,05 \\
\hline & $\begin{array}{l}\text { Pelabuhan Kuala Tanjung masuk ke dalam Rencana Induk } \\
\text { PelabuhanNasional (RIPN) }\end{array}$ & 0,0008 & 2 & 0,00 \\
\hline & Perairan pelabuhan memiliki kedalaman 20 LWS & 0,0000 & 2 & 0,00 \\
\hline & Jumlah & 1,00 & & 3,86 \\
\hline \multirow{7}{*}{$\begin{array}{l}\text { Kelemahan } \\
\text { (W) }\end{array}$} & Lamanya pembangunan infrastruktur (2012-2018) & 0,0886 & 2 & 0,18 \\
\hline & Alokasi dana yang belum tercukupi mencapai $\pm \mathrm{Rp} 37,8 \mathrm{~T}$ & 0,8860 & 2 & 1,77 \\
\hline & $\begin{array}{l}\text { Tingkat koordinasi instansi pemerintah (pusat dan daerah) } \\
\text { masih terbatas }\end{array}$ & 0,0246 & 2 & 0,05 \\
\hline & Akses jalan yang belum menggunakan jalan nasional & 0,0000 & 4 & 0,00 \\
\hline & $\begin{array}{l}\text { Penggunaan teknologi operasional pelabuhan yang belum } \\
\text { optimal }\end{array}$ & 0,0008 & 3 & 0,00 \\
\hline & Jumlah & 1,00 & & 2,00 \\
\hline & EKSTERNAL & & & \\
\hline \multirow{6}{*}{ Peluang (O) } & $\begin{array}{l}\text { Adanya kawasan industri Sei Mangke di sekitar lokasi } \\
\text { pelabuhan }\end{array}$ & 0,0886 & 2 & 0,18 \\
\hline & $\begin{array}{l}\text { Jalur Perdagangan dunia dengan jumlah petikemas yang } \\
\text { lewat } 51 \text { jt TEU's }\end{array}$ & 0,8860 & 2 & 1,77 \\
\hline & $\begin{array}{l}\text { Pelabuhan Kuala Tanjung dapat menjadi international hub } \\
\text { port di wilayah barat Indonesia dengan pengembangan } \\
\text { mencapai } 25 \text { jt TEU's }\end{array}$ & 0,0246 & 2 & 0,05 \\
\hline & $\begin{array}{l}\text { Pelabuhan Kuala Tanjung menjadi pendukung pelabuhan } \\
\text { sebelumnya (Belawan dan Dumai) }\end{array}$ & 0,0000 & 4 & 0,00 \\
\hline & Dapat menurunkan biaya logistik nasional hingga 10\% & 0,0008 & 3 & 0,00 \\
\hline & Jumlah & 1,00 & & 2,00 \\
\hline \multirow{6}{*}{$\begin{array}{l}\text { Ancaman } \\
(\mathrm{T})\end{array}$} & $\begin{array}{l}\text { Pelabuhan pesaing di Selat Malaka (Singapura dan Malaysia) } \\
\text { yang menyerap pasar } 80 \%\end{array}$ & 0,8860 & 1 & 0,89 \\
\hline & Cina berkeinginan membuka jalur baru pelayaran dunia & 0,0886 & 2 & 0,18 \\
\hline & Pertumbuhan industri di Indonesia hanya 5\% per tahun & 0,0008 & 3 & 0,00 \\
\hline & $\begin{array}{l}\text { Penurunan produksi daerah interland karena konversi lahan } \\
\text { perkebunan }\end{array}$ & 0,0000 & 2 & 0,00 \\
\hline & ketidakpastian hukum dan investasi & 0,0246 & 3 & 0,07 \\
\hline & Jumlah & 0,98 & & 1,07 \\
\hline
\end{tabular}

Berdasarkan hasil analisis SWOT dan pembobotan nilai faktor-foktor strategi yang direkomendasikan pada strategi SO adalah mengoptimalkan letak Pelabuhan Kuala Tanjung yang stategis dan kedalaman perairan untuk mengambil pasar perairan dunia dan menjadi international hub port. Stategi yang direkomendasikan untuk strategi W-O adalah mendorong pemerintah untuk menyediakan kebutuhan infrastruktur dalam rangka memanfaatkan potensi Pelabuhan Kuala Tanjung 
dan penurunan biaya logistik. Stategi yang direkomendasikan untuk S-T adalah menguatkan posisi strategis Pelabuhan Kuala Tanjung dan tidak ikut mendukung pembukaan jalur baru pelayaran dunia. Strategi untuk W-T adalah mengambil pasar yang ada di Selat Malaka dengan melakukan pelayanan pelabuhan yang lebih baik dari pelabuhan lainnya di Selat Malaka.

Sedangkan berdasarkan penilaian terhadap faktor internal dan eksternal berdasarkan penilaian tertinggi adalah :

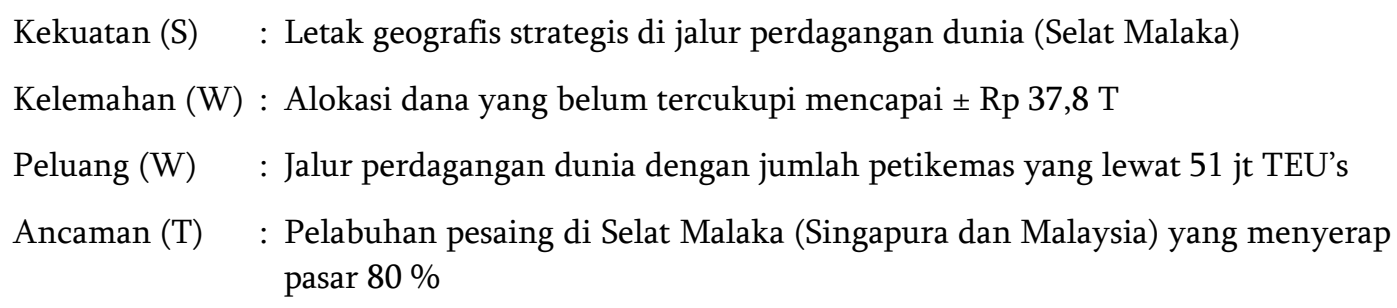

\section{KESIMPULAN DAN SARAN}

\section{Kesimpulan}

Berdasarkan hasil analisis SWOT terdapat 10 faktor internal yang terdiri dari 5 faktor kekuatan dan 5 faktor kelemahan. Faktor eksternal juga terdapat 10 faktor yang terdiri dari 5 faktor peluang dan 5 faktor ancaman.

Bedasarkan pembobotan nilai maka strategi S-O menjadi strategi prioritas yang perlu dilakukan dalam pengembangan Pelabuhan Kuala Tanjung.

\section{Saran}

Berdasarkan hasil penelitian ini pemerintah dan pihak terkait dapat mengambil strategi yang dapat dijadikan acuan untuk pengambilan kebijakan. Dalam penelitian ini data yang diambil merupakan data prokasi, hal ini disebabkan karena kondisi pelabuhan yang belum beroperasi namun telah selesai pembangunan sehingga pada dapat dikembangkan penelitian lanjutan dengan menggunakan data yang lebih akurat.

Selain itu pemerintah perlu memperbaiki berbagai aturan terkait tata cara pengiriman barang ekspor Indonesia dari yang selama ini ada, dengan menghimbau saja untuk menerapkan CIF pada tata cara pemberitahuan ekspor barang hanya merupakan sebuah pilihan bagi pengusaha angkutan laut nasional. Seharusnya kebijakan tersebut menjadikannya suatu kewajiban bukan hanya sekedar himbauan.

\section{DAFTAR PUSTAKA}

Adhiyakso Tettuko Wiwengku. 2012. Evaluasi Lokasi Pengembangan Pelabuhan Tanjung Perak, JURNAL TEKNIK ITS. Vol. 1, (Sept, 2012) ISSN: 2301-9271, Jurusan Teknik Perkapalan, Fakultas Teknologi Kelautan, Institut Teknologi Sepuluh Nopember (ITS).

Afrillita N. 2013. Analisis SWOT dalam menentukan strategi pemasaran sepeda motor pada PT. Samekarindo Indah di Samarindah. E Journal Administrasi Bisnis. 1(1): 56-70.

Bichou, K. 2013, Port Operations, Planning and Logistics, Informa Law, Roudlatge, New York, USA

David FR, 2012. Manajement Stategis Ed.ke -12 Jakarta (ID), Salemba, Jakarta.

David ME, Forest RD, Fred RD 2009. The Quantitative Stategic Planning Matrix (QSPM) applied to retail computer store. 
Djohar, Saptono. 2008. Teknik Perencanaan Strategik: Bahan Kuliah. Bogor (ID): Program Pasca Sarjana Manajemen dan Bisnis Institut Pertanian Bogor.

Kastanya Jori George Kherel. 2013. Perencanaan Pengembangan Pelabuhan Laut Serui di Kota Serui Papua, Jurnal Sipil Statik Vol.1 No.4, Maret 2013 (233-239) ISSN: 2337-6732.

Kementerian Perhubungan Republik Indonesia. 2016. Peraturan Menteri Perhubungan Republik Indonesia Nomor PM. 20 Tahun 2012 tentang Rencana Induk Pelabuhan Kuala Tanjung. Jakarta (ID): Kemenhub RI.

Kementerian Perhubungan Republik Indonesia. 2012. Rencana Induk Pelabuhan Kuala Tanjung, Jakarta.

Lasse DA . 2011. Manajemen Kepelabuhanan, Devisi Buku Perguruan Tinggi, PT. Raja Grafindo Persada, Jakarta.

Nainggolan B.P AM, D.A.Soeboer, S. Rahardjo, 2017 Peluang dan Tantangan Angkutan Laut Luar Negeri Oleh Kapal Berbendera Indonesia terhadap barang yang Diangkut dari Pelabuhan Belawan. Warta Penelitian Perhubungan Vol. 29 No.1, 2017.

Nazir M, 1999. Metode Penelitian, Ed ke -4 Jakarta (ID). PT Ghalia Indonesia.

Oktavina R. 2009. Model manajemen strategis evaluasi kinerja usaha mikro dan kecil makanan ringan. Jurnal Ekonomi Bisnis. 2(14): 88-98.

Pemerintah RI. 2008. Undang-Undang Nomor 17 Tahun 2008 tentang Pelayaran (Lembaran Negara Republik Indonesia Tahun 2008 Nomor 64, Tambahan Lembaran Negara Republik Indonesia Nomor 4849). Jakarta (ID): Pemerintah RI.

Rangkuti F. 2001. Analisis SWOT Teknik Membedah Kasus Bisnis. Jakarta (ID): PT. Gramedia Pustaka Utama.

Sotiono, BA. 2010. Analisis Faktor-faktor yang mempengaruhi kinerja pelabuhan. Jurnal Aplikasi Pelayaran dan Kepelabuhanan. 1(1);39-60.

Suhartini. 2012. Analisis SWOT dalam menentikan strategi pemasaran pada perusahaan. MATRIK. 7(2):1-7.

Tseng MM, Qinhai M, Su CJ. 1999. Mapping customers' services experience for operations improvement. Business Process Management Journal. 5(1): 50-59.

Wibowo W. 2009. Analisis internal \&eksternal; (IE) matrik dalam strategi pengembangan objek wana wisata Grajagan. Jurnal ekonomi bisnis. 14 2(2): 161-170. 